Received 06.04.2017 Reviewed 18.07.2017 Accepted 25.07.2017

A - study design

B - data collection

C - statistical analysis

D - data interpretation

E - manuscript preparation

F - literature search

\section{Community engagement for irrigation water management in Lao PDR}

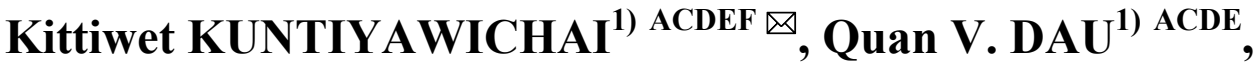 \\ Saengdavanh INTHAVONG ${ }^{2)}$ BEF
}

1) Khon Kaen University, Department of Civil Engineering, 123 Moo 16 Mittapap Rd., Nai-Muang, Muang District, Khon Kaen 40002, Thailand; e-mail: kittiwet@gmail.com, infohquan@gmail.com

${ }^{2)}$ Ministry of Agriculture and Forestry, Department of Irrigation, Vientiane, Lao PDR; e-mail: saeng2010@gmail.com

For citation: Kuntiyawichai K., Dau Q.V., Inthavong S. 2017. Community engagement for irrigation water management in Lao PDR. Journal of Water and Land Development. No. 35 p. 121-128. DOI: 10.1515/jwld-2017-0075.

\begin{abstract}
Sustainable water resources management and community engagement are essential for water security. Referring to the above context, this study proposed to carry out an assessment of community engagement for irrigation water management in the Nam Haad Left Irrigation Project (NHLIP). The household and community level practices and the farmers' levels of participation in irrigation water management of the NHLIP were carefully considered. From respondents' responses, the results revealed that a husband-wife partnership plays a remarkable role in irrigation water management of the NHLIP for rice farming. The results also proved that most of the respondents engage with a high participation level in managing irrigation water of the NHLIP project as illustrated by a high score of 3.80 on the five-point Likert scale. To determine the significance of each activity on farmers' levels of participation in irrigation water management of the NHLIP, a stepwise multiple regression analysis was employed and the standardized regression equation for determining overall participation levels can be presented as: $Y=0.538 x_{1}+0.831 x_{8}+0.534 x_{14}+0.607 x_{18}+7.572$. Finally, the outcomes of this study indicated the willingness of participation in cooperating and supporting the activities related to the improvement and management of the NHLIP project.
\end{abstract}

Key words: community involvement, irrigation management, Statistical Package for Social Sciences (SPSS), stepwise multiple regression, Water User Group

\section{INTRODUCTION}

Lao PDR is known as a land-locked country, which significantly relies on natural resources and its agricultural productivity. Based on the report published by the Ministry of Agriculture and Forestry (MAF) in 2013, it stated that numerous efforts have been put in place to support and alleviate the poverty of the rice farmers and also to promote the development of agricultural sector [Ministry of Agriculture and Forestry 2013]. For instance, one of those efforts is the establishment of a single family farm, community, and also large-scale irrigation systems. Despite the fact that the irrigation and drainage systems in Lao PDR, i.e. irrigation and drainage canals, head works, etc. already exist, however, the efficiency of water allocation and water supply for service areas is still somewhat doubtful as its system becomes deteriorated [Phonemany, KuntiYawichai 2016]. That is to say, the system still needs to be upgraded and maintained annually and substantially, so that the issues of low productivity, inadequate water supply, and expensive production cost can be avoided [SIVANGPHENG et al. 2014]. In this regard, this study aims to focus on the irrigation systems of Bokeo Province, Lao PDR, where it is known as a problematic area for irrigation 


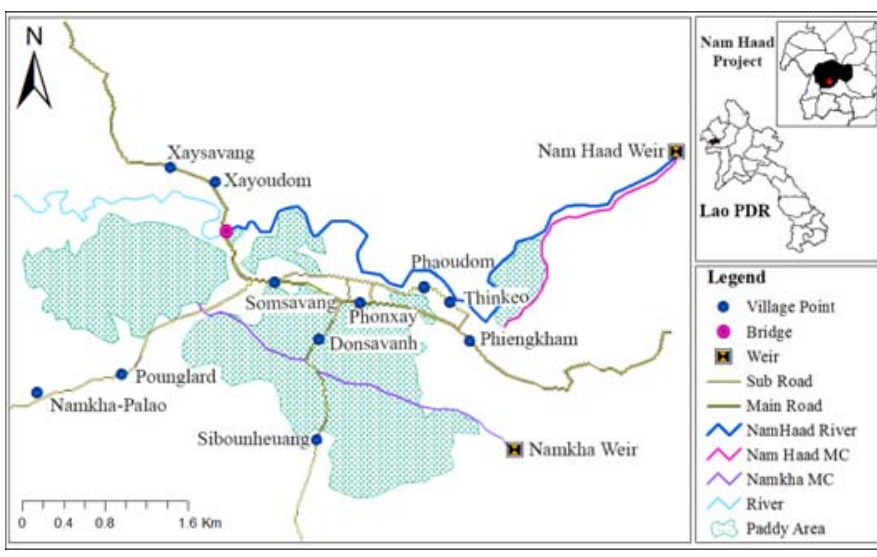

Fig. 1. Map of the Nam Haad Left Irrigation Project; source: own elaboration

water management nowadays. A careful consideration of farmer practices for the sustainability of the community-based irrigation water management systems was also taken into account for this study.

It is well recognized that the involvement of farmers in managing irrigation water distribution can induce the increase in farm productivity and the improvement of irrigation systems [GROENFELDT, SUN 2016]. In addition, the farmers also need to be encouraged to join the Water User Group (WUG) for participatory management of irrigation water and its systems in their respective areas [ALAN 2016]. As can be learnt from the case of Taiwan, the water is allocated based on irrigation plans and it is managed by water-guards who are local farmers of the respective community [LAM 1996]. The irrigation water management systems can also be transferred from the state to users (i.e. WUAs and farmer unions) as suggested by the findings from the case of Turkey [YERCAN 2003]. Moreover, the irrigation water management systems can also be managed in association with the Water Framework Directive [MIODUSZEWSKI 2006]. Besides the important role of farmers in improving irrigation systems, there are several approaches that have been established in the past, e.g. the formulation of agro-climatic zoning strategy [NORELDIN et al. 2016], the use of soil moisture sensor technology [CEPUDER, NOLZ 2007], etc. In relation to the evaluation of community engagement in irrigation water management and level of ownership of farmers, this study would be very useful to provide the understanding and knowledge in managing the community-based irrigation water management systems, especially in Phaoudom District, Bokeo Province, Lao PDR.

\section{MATERIALS AND METHODS}

\section{STUDY AREA}

This study focused on the Nam Haad Left Irrigation Project (NHLIP), situated in Phaoudom District, Bokeo Province, Northwestern of Lao PDR (Fig. 1). In details, Phaoudom District has a total area of ap- proximately $1,579 \mathrm{~km}^{2}$, with the population estimated to be about 36,400 people in 2015 . In the study area, the Nam Haad River is known as the major river with about $7 \mathrm{~km}$ in length, which is used to supply water for irrigation and livelihood. In Phaoudom District, there are two main canals (MC), i.e. Nam Haad MC $2.07 \mathrm{~km}$ and Namkha MC $3.36 \mathrm{~km}$. In view of meteorological situation, during the period of 2001 to 2009, Phaoudom District has a warm temperature climate in which the dry season is from November to February while the wet season is from May to October. The mean daily temperature was estimated to be $21^{\circ} \mathrm{C}$, while the minimum temperature was recorded to be $13.5^{\circ} \mathrm{C}$ in January 2009 and the maximum temperature reached $35.1^{\circ} \mathrm{C}$ in April 2001. The mean annual rainfall was estimated to be approximately $1,846 \mathrm{~mm}$ with the highest monthly rainfall of $652.9 \mathrm{~mm}$ in July 2008. The average relative humidity at Bokeo meteorological station was found to be from $25 \%$ to $76 \%$ (between March and July) and from $82 \%$ to $97 \%$ (between March and September). The mean annual evaporation was observed to be $1,601 \mathrm{~mm} \cdot \mathrm{year}^{-1}$ with the minimum evaporation of $68.2 \mathrm{~mm} \cdot \mathrm{month}^{-1}$ recorded in May 2001 and the maximum of $257 \mathrm{~mm} \cdot \mathrm{month}^{-1}$ recorded in March 2004 [ADB 2015]. According to the MAF, the NHLIP's beneficiaries were estimated to be about 1,116 households with a total population of 4,311 people in 2013, as shown the details in Table 1 (note: all beneficiaries were from 11 villages, i.e. Phaoudom, Thinkeo, Phonxay, Pounglard, Sibounheuang, Phiengkham, Xaysavang, Namkha-Palao, Somsavang, Xayoudom, and Donsavanh).

Table 1. General information and beneficiary of villages in Phaoudom District

\begin{tabular}{|l|r|r|r|c|}
\hline \multirow{2}{*}{ Village } & \multicolumn{2}{|c|}{ General information } & \multicolumn{2}{c|}{ Beneficiary } \\
\cline { 2 - 5 } & household & population & household & population \\
\hline Phaoudom & 216 & 1133 & 73 & 385 \\
\hline Phonxay & 151 & 853 & 52 & 336 \\
\hline Phiengkham & 95 & 557 & 443 & 278 \\
\hline Thinkeo & 166 & 939 & 96 & 592 \\
\hline Pounglard & 135 & 704 & 63 & 329 \\
\hline Sibounheuang & 82 & 435 & 65 & 359 \\
\hline Xaysavang & 51 & 251 & 34 & 178 \\
\hline Namkha-Palao & 112 & 644 & 77 & 470 \\
\hline Somsavang & 150 & 854 & 63 & 382 \\
\hline Xayoudom & 160 & 1072 & 101 & 707 \\
\hline Donsavanh & 63 & 358 & 49 & 295 \\
\hline \multicolumn{1}{|c|}{ Total } & 1381 & 7800 & 1116 & 4311 \\
\hline
\end{tabular}

Note: beneficiary group is indicated only in the irrigated area. Source: own study.

\section{DATA ANALYSIS}

The data for this study was collected at Phaoudom District from questionnaire survey and in-depth interview using Key Information Interview (KII) method, which was undertaken in Lao language in 
2016. The KII approach was used to identify the experts who are able to corporate and lead the NHLIP project for effective irrigation water management system. To analyse the obtained survey data, the Statistical Package for Social Sciences (SPSS) which is a widely used program for statistical analysis and handling complex data manipulations and analyses, was used.

The surveying was conducted by selecting a random number of respondents in the study area. The number of respondents was calculated by using Taro Yamane formula as presented in Equation 1, with a $90 \%$ confidence level and a sampling error tolerance level of $10 \%$.

$$
n=\frac{N}{1+\left(N \cdot e^{2}\right)}
$$

where: $n=$ sample size; $N=$ total population; $e=$ level of precision at $90 \%$ confidence interval.

Among all sample sizes, there were 9 respondents to be selected as the key informants of this study. The selected key informants comprised some of the officials from the NHLIP project, i.e. 2 chiefs, 4 deputy chiefs, 2 accountants of the water user group, and 1 chief of the rice seed group. They were selected because of their abilities and direct involvement to the project. They were interviewed individually at their convenient time (note: during the period of data collection at either indoor or outdoor of their workplaces). The interviewing process was conducted based upon the KII guide question that best fits the research objectives and the contents of survey questionnaires. Furthermore, the classification of participation level of respondents was given on a discrete scale, the so-called "Likert scale", which is the most widely used method to scale responses in survey research (Tab. 2).

Table 2. Rating scale as classified by Likert scale

\begin{tabular}{|c|c|}
\hline Score & Rating \\
\hline $4.20-5.00$ & very high \\
\hline $3.40-4.19$ & high \\
\hline $2.60-3.39$ & moderate \\
\hline $1.80-2.59$ & low \\
\hline $1.00-1.79$ & very low \\
\hline
\end{tabular}

Source: own study.

To determine the participation level of farmers in this study, as refers to [DYMERSKA et al. 2012; MIRDAMADI et al. 2016; SIVANGPHENG et al. 2014], the stepwise multiple regression analysis was used based on the given activities as shown in Equation 2.

$$
Y=B_{1} x_{1}+B_{2} x_{2}+B_{3} x_{3}+\ldots+B_{n} x_{n}+a
$$

where: $Y=$ the score of participation in irrigation system; $B_{1}, \ldots, B_{n}=$ the coefficient of correlation between the control variable (based on a 5-point Likert scale) and predicted variable; $x_{1}, \ldots x_{n}=$ the study activity variables; $a=$ a constant variable.

\section{RESULTS AND DISCUSSION}

By using Taro Yamane formula, Equation 3 shows the calculation of number of respondents to be interviewed in Phaoudom Village and it was found to be approximately 68 .

$$
n=\frac{N}{1+\left(N \cdot e^{2}\right)}=\frac{216}{1+\left(216 \cdot 0.10^{2}\right)}=68.35
$$

However, it should be noted that some respondents might not respond or answer the questions being asked and this can lead to unrepresentative and biased results. To compensate this possible shortcoming, the sample size should be increased by $10 \%$. Therefore, the proposed/actual sample size $(n)$ should be equal to $68.35+(68.35 \cdot 10 \%)=75.19$ or 75 (note: 9 respondents were selected as the key informants whereas 66 respondents were interviewed as supporting informants).

In details, respondents were asked to respond to a statement in one of five response categories that range from "very high" to "very low". At the household level, based on the experience and knowledge of the respondents, there are 12 practical activities that the respondents contribute to the Nam Haad Left Irrigation Project (NHLIP), such as: (1) and (2) opening and closing the secondary canal gates in their own rice field, respectively; (3) repairing the irrigation canals; (4) maintaining the irrigation canals; (5) attending the meetings related to operation and management of irrigation system; (6) updating the knowledge on operation and management of irrigation system by listening to the radio; (7) updating the knowledge by reading leaflets; (8) updating the knowledge by reading books; (9) updating the knowledge by discussing with the household members; (10) taking note and discussing problems related to the irrigation project; (11) taking note and discussing the positive impacts (strengths) of the irrigation project; and (12) discussing with the entire family on the issues related to the irrigation project.

In this study, the Statistical Package for Social Sciences (SPSS) program was used for handling the survey data. The results illustrated in Figure 2 reveal that rice farming is mainly a husband-wife partnership

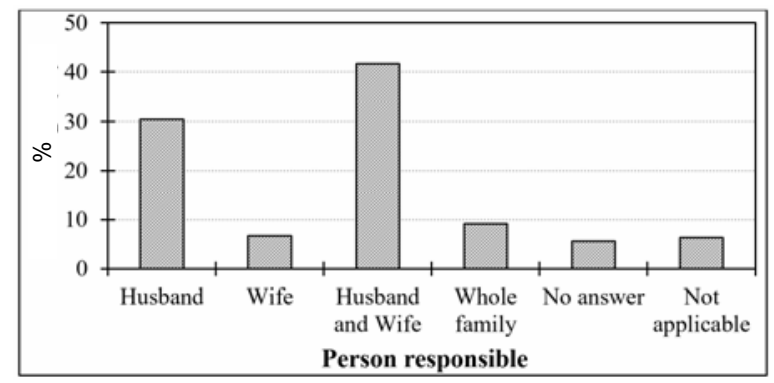

Fig. 2. Percentage of household participation in irrigation water management in the Nam Haad Left Irrigation Project; source: own study 
Table 3. Household participation in irrigation water management in the Nam Haad Left Irrigation Project

\begin{tabular}{|c|c|c|c|c|c|c|c|}
\hline \multirow{3}{*}{ Activity } & \multicolumn{7}{|c|}{ Responsible person } \\
\hline & husband & wife & $\begin{array}{l}\text { husband } \\
\text { and wife }\end{array}$ & $\begin{array}{l}\text { whole } \\
\text { family }\end{array}$ & no answer & $\begin{array}{c}\text { not } \\
\text { applicable }\end{array}$ & total \\
\hline & $n(\%)$ & $n(\%)$ & $n(\%)$ & $n(\%)$ & $n(\%)$ & $n(\%)$ & $\sum n(\%)$ \\
\hline Opening the gate(s) & $43(65.2)$ & - & $16(24.2)$ & $4(6.1)$ & $3(4.5)$ & - & $66(100)$ \\
\hline Closing the gate(s) & $32(48.5)$ & - & $22(33.3)$ & $9(13.6)$ & $3(4.5)$ & - & $66(100)$ \\
\hline Repairing the irrigation canals & $22(33.3)$ & - & $21(31.8)$ & $21(31.8)$ & $2(3.0)$ & - & $66(100)$ \\
\hline Maintaining the irrigation canals & $11(16.7)$ & - & $38(57.6)$ & $15(22.7)$ & $2(3.0)$ & - & $66(100)$ \\
\hline Attending meetings & $26(39.4)$ & $2(3.0)$ & $34(51.5)$ & $2(3.0)$ & $2(3.0)$ & - & $66(100)$ \\
\hline Updating knowledge by listening to the radio & $19(28.8)$ & $1(1.5)$ & $29(43.9)$ & $9(13.6)$ & $4(6.1)$ & $4(6.1)$ & $66(100)$ \\
\hline Updating knowledge by reading leaflets & $14(21.2)$ & $6(9.1)$ & $30(45.5)$ & $2(3.0)$ & $9(13.6)$ & $5(7.6)$ & $66(100)$ \\
\hline Updating knowledge by reading books & $17(25.8)$ & $14(21.2)$ & $24(36.4)$ & $1(1.5)$ & $5(7.6)$ & - & $66(100)$ \\
\hline $\begin{array}{l}\text { Updating knowledge by discussing with the } \\
\text { household members }\end{array}$ & $11(16.7)$ & - & $47(71.2)$ & - & $5(7.6)$ & $2(3.0)$ & $66(100)$ \\
\hline $\begin{array}{l}\text { Taking note and discussing problems related } \\
\text { to the project }\end{array}$ & $20(30.3)$ & $14(21.2)$ & $26(39.4)$ & $1(1.5)$ & $5(7.6)$ & - & $66(100)$ \\
\hline $\begin{array}{l}\text { Taking note and discussing positive impacts/ } \\
\text { strengths of the project }\end{array}$ & $19(28.8)$ & - & $37(56.1)$ & $1(1.5)$ & $5(7.6)$ & - & $66(100)$ \\
\hline Discussing among the entire family members & $14(21.2)$ & $1(1.5)$ & $45(68.2)$ & $1(1.5)$ & $5(7.6)$ & - & $66(100)$ \\
\hline
\end{tabular}

Explanation: $n(\%)=$ the number of respondents and its percentage compared to the total number of respondents.

Source: own study.

(about $42 \%$ of the total respondents) in irrigation water management in the NHLIP.

As presented in Table 3, there are about $65.2 \%$ of respondents answered that the husband is the primary manpower for gate opening to supply the irrigation water to their own rice fields, whereas about $48.5 \%$ involves with gate closing. About the repairing of irrigation canals, the results suggested that almost all respondents agreed with the mutual responsibility for this particular task (note: $33.3 \%, 31.8 \%$, and $31.8 \%$ of respondents answered that it should be under the responsibility of husband, husband and wife, and the whole family, respectively). The majority of respondents $(57.6 \%)$ indicated that the maintenance of irrigation canals should be the role for both husband and wife. Likewise, approximately $51.5 \%$ of respondents prioritized the primary importance of attending meetings related to proper operation and management of irrigation system for both husband and wife. Moreover, with the development of a wide variety of media technology and other media devices, both husband and wife will have more access to gain more knowledge on the expansion of their irrigation system by listening to the radio programs, reading leaflets and books, taking a note, and discussing about the irrigation project among the entire family members.

It is a crucial fact that conducting an effective interview is a critical element for determining farmers' levels of participation in irrigation water management of the NHLIP. The following four phases, which serve to ensure the purpose and direction of the interview and also help to define the desired outcomes/ benefits over the long-term sustainable and costeffective way, can be presented as follows.

- Phase 1. Setting the stage starts with introductions and takes place before an agenda is set. In details, this phase involved the invitation of farmers who are engaged with the irrigation water management of the NHLIP to have a discussion about the pro- ject vision, mission, and goals $\left(x_{1}\right)$. Next, a constructive environment for dialogue was created by allowing the farmers to get to know each other $\left(x_{2}\right)$. During the meeting, a determination of initial leadership and organizational management was carried out to ensure that a leadership or management core team is in place $\left(\boldsymbol{x}_{\mathbf{3}}\right)$. Thereafter, the purpose and process of the project was outlined and discussed with the help of facilitator $\left(\boldsymbol{x}_{4}\right)$. This phase ended up with the determination of interest for further discussions and setting up for phase 2 $\left(x_{5}\right)$.

- Phase 2. Gathering information intends to identify relevant issues that need to be addressed for the following in-depth investigation. Firstly, an appropriate and encouraging environment was established for asking questions, expressing hesitation/doubts, and brainstorming and sharing new ideas $\left(\boldsymbol{x}_{\mathbf{6}}\right)$. Then, the relevant and necessary information was gathered through SWOT analysis in which the farmers discussed the NHLIP project's (internal) strengths and weaknesses, as well as (external) opportunities and threats influencing the management of irrigation water of the NHLIP, in conjunction with the other tools such as Appreciative Inquiry (AI), asset mapping, etc. $\left(x_{7}\right)$. The issues related to community's values, ethics, vision, and mission were also clarified, together with the establishment of the common ground for increased collaboration (before start discussing) $\left(x_{8}\right)$. After that, the alternative solutions were derived from "what if" questions (through brainstorming, critical thinking, and discussion), which covered the options, the alignment with the vision, and the potential impacts $\left(\boldsymbol{x}_{9}\right)$. The selection of the best practice/solution was made accordingly (note: too many choices lead to confusion) $\left(x_{10}\right)$. Eventually, the decision was made based on the farmer's readiness to move to phase $3\left(x_{11}\right)$. 
- Phase 3. Planning and reviewing is an important process as every review leads to a plan and every plan needs to be reviewed. This phase involves the identification of what has to be done, by whom, at what cost and when. In brief, phase 3 started with drafting the implementation action plan based on the inputs from the planning teams (from each topic area), including its evaluation procedures. The identification of costs, involved and responsible persons, timeline setting, progress-monitoring measures, and action status, were also considered $\left(x_{12}\right)$. Later, the proposed implementation action plan was discussed with the involved farmers/communities for insight and decision making purposes $\left(x_{13}\right)$. The proposed implementation action plan was reviewed, assessed, and revised accordingly based on the feedbacks received from involved members $\left(\boldsymbol{x}_{\mathbf{1 4}}\right)$. At last, the decision was made based on the farmer's readiness to move to phase $4\left(x_{15}\right)$.

- Phase 4. Implementation, monitoring, and evaluation provides a series of strategies and guidelines for implementing the project. In particular, the negotiation and finalization of funding agreements was conducted with the oversight committees $\left(x_{16}\right)$. Identification/naming of staffs and members for the management team was also made by promoting key persons who have leadership potential and demonstrated readiness for greater responsibilities from different divisions and various backgrounds $\left(x_{17}\right)$. Next, the implement of the plan was undertaken by ensuring that the members distribute the power, offer recognition, communicate among each other, and respect the roles of the members (note: certainly, the success can be assured if the implementation of the action plan is expected to be effective in case it operates with good governance and a focus on financial sustainability, risk management, and legislative compliance) $\left(x_{18}\right)$. The project progress and performance was then monitored to identify variation from the plan and recommend preventive and corrective actions to ensure the delivery of the project in line with the planned expectations $\left(x_{19}\right)$. After that, the current status and project impacts were noted and evaluated based on feedbacks gathered from farmers/communities $\left(\boldsymbol{x}_{\mathbf{2} 0}\right)$. Finally, the implementation plan was re-evaluated and revised based on the actual impacts and the farmer/community feedbacks (note: this step may involve any of the previous steps) $\left(x_{21}\right)$.

Based on the survey data and Likert scale, the respondents' responses on farmers' levels of participation in irrigation water management of the NHLIP was analysed and classified into five levels, i.e. very high (5), high (4), moderate (3), low (2), and very low (1). As can be seen in Table 4, the respondents possessed a "high" level of involvement in irrigation water management of the NHLIP. This is clearly shown by the score for each statement of each phase that falls between 3.40 and 4.19 and also the overall mean score of 3.80 on 1-5 Likert scale (note: the mean score was calculated using SPSS software by summing the ratings of all the respondents and dividing that sum by the number of respondents). Besides that, a column for "Not applicable" was also included to record the percentage of respondents who are not able to respond to a statement in survey questions and also to assess respondents' level of comprehension. In details, by considering phase 1 to phase 4 , it was found that most of the respondents engaged with a high participation level in all irrigation water management activities in the NHLIP (i.e. around $51.0 \%$ to $63.7 \%$ of the total number of respondents) as indicated in Figure 3.

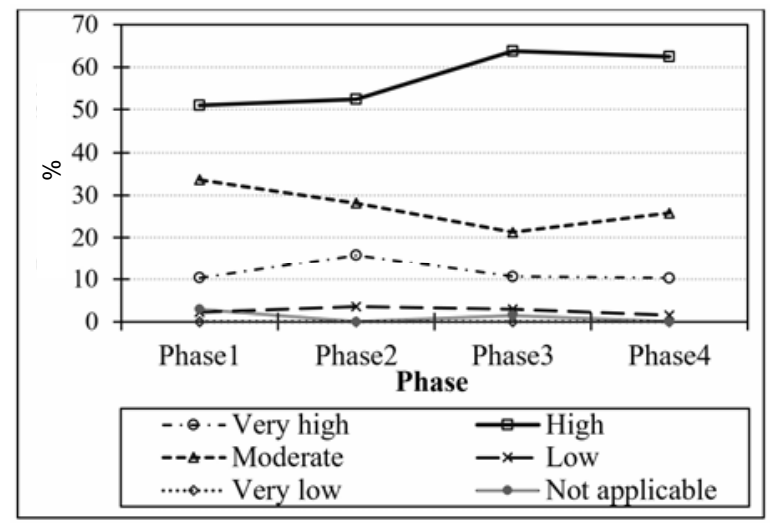

Fig. 3. Percentage of respondents engaged with different participation levels for each phase of irrigation water management activities in the Nam Haad Left Irrigation Project; own study

Although this study was successfully undertaken for certain issues, there are still some challenges that urge farmers and farmer leaders to reconsider in the future such as: (1) time constraint in discussing problems among farmers and farmer leaders, (2) difference in understanding of farmers related to "problemfocused thinking" and "solution-focused thinking", and (3) the SWOT (Strengths, Weaknesses, Opportunities, and Threats) analysis and other assessment tools such as Appreciative Inquiry (AI), asset mapping, etc. are not yet familiar for the farmers at this moment.

To evaluate the significance of each activity on farmers' levels of participation in irrigation water management of the NHLIP, the determination coefficient $\left(R^{2}\right)$ and the independent samples $t$-test were used to explain the goodness-of-fit and to compare the mean difference between predictors and control variables, respectively. Moreover, the Durbin-Watson statistic test was also used to describe the autocorrelation in the residuals from a statistical regression analysis. The values of Durbin-Watson statistic range between 0 and 4, in which 0 represents positive autocorrelation and 4 represents negative autocorrelation. From the results of stepwise multiple regression analysis, various activities related to meeting on project vision, 
Table 4. Respondents' responses on farmers' levels of participation in irrigation water management of the Nam Haad Left Irrigation Project

\begin{tabular}{|c|c|c|c|c|c|c|c|c|c|}
\hline \multirow{3}{*}{ Statement } & \multicolumn{7}{|c|}{ Response } & \multirow{3}{*}{ Mean } & \multirow{3}{*}{$\begin{array}{l}\text { Level of } \\
\text { partici- } \\
\text { pation }\end{array}$} \\
\hline & \multirow{2}{*}{\begin{tabular}{|c|} 
very high \\
$n(\%)$ \\
\end{tabular}} & \multirow{2}{*}{$\begin{array}{l}\text { high } \\
n(\%)\end{array}$} & \multirow{2}{*}{$\begin{array}{c}\text { moderate } \\
n(\%)\end{array}$} & \multirow{2}{*}{$\frac{\text { low }}{n(\%)}$} & \multirow{2}{*}{$\begin{array}{c}\text { very low } \\
n(\%)\end{array}$} & \multirow{2}{*}{\begin{tabular}{c|}
$\begin{array}{c}\text { not } \\
\text { applicable }\end{array}$ \\
$n(\%)$ \\
\end{tabular}} & \multirow{2}{*}{$\begin{array}{c}\text { total } \\
\sum n(\%)\end{array}$} & & \\
\hline & & & & & & & & & \\
\hline \multicolumn{10}{|c|}{ Phase 1 - setting the stage } \\
\hline $\begin{array}{l}\text { Meeting on project vision, mission, } \\
\text { and goals }\left(x_{1}\right)\end{array}$ & $8(12.1)$ & $46(69.7)$ & $10(15.2)$ & - & - & $2(3.0)$ & $66(100)$ & 3.85 & high \\
\hline $\begin{array}{l}\text { Getting to know the other members } \\
\text { of the group }\left(x_{2}\right)\end{array}$ & $11(16.7)$ & $26(39.4)$ & $28(42.2)$ & $1(1.5)$ & - & - & $66(100)$ & 3.71 & high \\
\hline $\begin{array}{l}\text { Forming the core group of leaders } \\
\left(x_{3}\right)\end{array}$ & $6(9.1)$ & $34(51.5)$ & $24(36.4)$ & $2(3.0)$ & - & - & $66(100)$ & 3.67 & high \\
\hline $\begin{array}{l}\text { Defining and discussing on the } \\
\text { project }\left(x_{4}\right)\end{array}$ & $4(6.1)$ & $33(50.0)$ & $28(42.4)$ & $1(1.5)$ & - & - & $66(100)$ & 3.61 & high \\
\hline $\begin{array}{l}\text { Measuring the interest of the mem- } \\
\text { bers on the project }\left(x_{5}\right)\end{array}$ & $6(9.1)$ & $34(51.5)$ & $24(36.4)$ & $2(3.0)$ & - & - & $66(100)$ & 3.67 & high \\
\hline \multicolumn{10}{|c|}{ Phase 2 - gathering information } \\
\hline $\begin{array}{l}\text { Open discussion for asking ques- } \\
\text { tions, expressing hesitation, and } \\
\text { sharing new ideas }\left(x_{6}\right)\end{array}$ & $8(12.1)$ & $37(56.1)$ & $19(28.8)$ & $2(3.0)$ & - & - & $66(100)$ & 3.77 & high \\
\hline $\begin{array}{l}\text { Gathering information using SWOT } \\
\text { analysis and other tools }\left(x_{7}\right)\end{array}$ & $8(12.1)$ & $29(43.9)$ & $25(37.9)$ & $4(6.1)$ & - & - & $66(100)$ & 3.62 & high \\
\hline $\begin{array}{l}\text { Clarifying the alignment of issues } \\
\text { with the community's values, ethics, } \\
\text { vision, and mission }\left(x_{8}\right)\end{array}$ & $17(25.8)$ & $33(50.0)$ & $14(21.2)$ & $2(3.0)$ & - & - & $66(100)$ & 3.98 & high \\
\hline $\begin{array}{l}\text { Asking alternative solutions ("what } \\
\text { if" questions) }\left(x_{9}\right)\end{array}$ & $14(21.2)$ & $31(47.0)$ & $19(28.8)$ & $2(3.0)$ & - & - & $66(100)$ & 3.86 & high \\
\hline Selecting the best solution $\left(x_{10}\right)$ & $6(9.1)$ & $34(51.5)$ & $24(36.4)$ & $2(3.0)$ & - & - & $66(100)$ & 3.67 & high \\
\hline $\begin{array}{l}\text { Farmer leaders' determination if the } \\
\text { members are ready to move to the } \\
\text { next phase }\left(x_{11}\right)\end{array}$ & $10(15.2)$ & $45(68.2)$ & $11(16.7)$ & - & - & - & $66(100)$ & 3.98 & high \\
\hline \multicolumn{10}{|c|}{ Phase 3 - planning and reviewing } \\
\hline $\begin{array}{l}\text { Writing the implementation plan } \\
\left(x_{12}\right)\end{array}$ & $6(9.1)$ & $37(56.1)$ & $23(34.8)$ & - & - & - & $66(100)$ & 3.74 & high \\
\hline $\begin{array}{l}\text { Discussion with the members/ } \\
\text { community on the implementation } \\
\text { plan }\left(x_{13}\right)\end{array}$ & $6(9.1)$ & $42(63.6)$ & $18(27.3)$ & - & - & - & $66(100)$ & 3.82 & high \\
\hline $\begin{array}{l}\text { Revision of the implementation plan } \\
\text { based on feedbacks received from } \\
\text { the members }\left(x_{14}\right)\end{array}$ & $7(10.6)$ & $46(69.7)$ & $12(18.2)$ & - & - & $1(1.5)$ & $66(100)$ & 3.92 & high \\
\hline $\begin{array}{l}\text { Farmer leaders' determination if the } \\
\text { members are ready to move to the } \\
\text { next phase }\left(x_{15}\right)\end{array}$ & $10(15.2)$ & $49(74.2)$ & $5(7.6)$ & $2(3.0)$ & - & - & $66(100)$ & 4.02 & high \\
\hline \multicolumn{10}{|c|}{ Phase 4 - Implementation, monitoring, and evaluation } \\
\hline Finalization of funding $\left(x_{16}\right)$ & $11(16.7)$ & $34(51.5)$ & $21(31.8)$ & - & - & - & $66(100)$ & 3.85 & high \\
\hline $\begin{array}{l}\text { Identification/naming of staffs and } \\
\text { members for the management team } \\
\left(x_{17}\right)\end{array}$ & $8(12.1)$ & $45(68.2)$ & $13(19.7)$ & - & - & - & $66(100)$ & 3.92 & high \\
\hline Implementation of the plan $\left(x_{18}\right)$ & $12(18.2)$ & $43(65.2)$ & $10(15.2)$ & $1(1.5)$ & - & - & $66(100)$ & 4.00 & high \\
\hline Monitoring the project progress $\left(x_{19}\right)$ & $4(6.1)$ & $49(74.2)$ & $12(18.2)$ & $1(1.5)$ & - & - & $66(100)$ & 3.85 & high \\
\hline $\begin{array}{l}\text { Noting and evaluating the project } \\
\text { impacts }\left(x_{20}\right)\end{array}$ & $3(4.5)$ & $33(50.0)$ & $29(43.9)$ & $1(1.5)$ & - & - & $66(100)$ & 3.58 & high \\
\hline $\begin{array}{l}\text { Revision and re-evaluation of im- } \\
\text { plementation plan based on the } \\
\text { actual impacts and the community } \\
\text { feedbacks }\left(x_{21}\right)\end{array}$ & $3(4.5)$ & $45(68.2)$ & $18(27.3)$ & - & - & - & $66(100)$ & 3.77 & high \\
\hline \multicolumn{8}{|c|}{ Overall mean score } & 3.80 & high \\
\hline
\end{tabular}

Explanation: $n(\%)=$ the number of respondents and its percentage compared to the total number of respondents.

Source: own study.

mission, and goals $\left(x_{1}\right)$ (phase 1 ); clarifying the alignment of issues with the community's values, ethics, vision, and mission $\left(x_{8}\right)$ (phase 2 ); revision of the implementation plan based on feedbacks received from the members $\left(x_{14}\right)$ (phase 3 ); and implementation of the plan $\left(x_{18}\right)$ (phase 4$)$, show a great significance lev- el as it has significant correlation with all control variables (i.e. $R^{2}>0.78$ ) with the statistical significance at 0.05 ( $p$-value $<0.05)$ as shown more details in Table 5 and Table 6 , respectively.

From the above regression output, a standardized regression equation in Equation 4 was established to 
Table 5. Correlations between the predictors and control variables

\begin{tabular}{|c|c|c|c|c|}
\hline Activity & Phase & $R^{2}$ & $\begin{array}{l}\text { Standard error } \\
\text { of the estimate }\end{array}$ & $\begin{array}{c}\text { Value of Durbin-Watson } \\
\text { statistic }\end{array}$ \\
\hline Meeting on project vision, mission, and goals $\left(x_{1}\right)$ & 1 & 0.79 & 7.76 & 1.34 \\
\hline $\begin{array}{l}\text { Clarifying the alignment of issues with the community's } \\
\text { values, ethics, vision, and mission }\left(x_{8}\right)\end{array}$ & 2 & 0.97 & 3.14 & 2.84 \\
\hline $\begin{array}{l}\text { Revision of the implementation plan based on feedbacks } \\
\text { received from the members }\left(x_{14}\right)\end{array}$ & 3 & 0.78 & 7.98 & 1.26 \\
\hline Implementation of the plan $\left(x_{18}\right)$ & 4 & 0.87 & 6.19 & 1.62 \\
\hline
\end{tabular}

Source: own study.

Table 6. The analysis results of predictors by stepwise multiple regression analysis

\begin{tabular}{|c|c|c|c|c|c|}
\hline \multirow{2}{*}{ Activity } & \multicolumn{2}{|c|}{ Unstandardized coefficient } & \multirow{2}{*}{$\begin{array}{c}\text { Standardized coefficient } \\
\beta\end{array}$} & \multirow{2}{*}{$t$-test } & \multirow{2}{*}{$p$-value } \\
\hline & $B$ & standard error & & & \\
\hline Meeting on project vision, mission, and goals $\left(x_{1}\right)$ & 0.538 & 0.134 & 0.918 & 4.012 & 0.028 \\
\hline $\begin{array}{l}\text { Clarifying the alignment of issues with the community's } \\
\text { values, ethics, vision, and mission }\left(x_{8}\right)\end{array}$ & 0.831 & 0.078 & 0.987 & 10.677 & 0.002 \\
\hline $\begin{array}{l}\text { Revision of the implementation plan based on feedbacks } \\
\text { received from the members }\left(x_{14}\right)\end{array}$ & 0.534 & 0.138 & 0.913 & 3.883 & 0.030 \\
\hline Implementation of the plan $\left(x_{18}\right)$ & 0.607 & 0.117 & 0.949 & 5.200 & 0.014 \\
\hline
\end{tabular}

Note: constant value $a$ is 7.572 and $p$-value is two-tailed significance level of $t$.

Source: own study.

determine the scores representing the participation levels in irrigation water management in the NHLIP.

$Y=0.538 x_{1}+0.831 x_{8}+0.534 x_{14}+0.607 x_{18}+7.572$

\section{CONCLUSION}

The assessment of the community engagement in irrigation water management in the Nam Haad Left Irrigation Project (NHLIP) was carried out in this study. The Statistical Package for Social Sciences (SPSS) was used for survey data processing and analysis. Based on the outcomes of this study, the results proved that most of the respondents are truly engaged with a high level of participation in the management of irrigation water of the NHLIP project as indicated by a high score of 3.80 on the five-point Likert scale. In addition, a standardized regression equation was established as follows: $Y=0.538 x_{1}+0.831 x_{8}+$ $0.534 x_{14}+0.607 x_{18}+7.572$, for determining the participation levels in irrigation water management in the NHLIP. The results also showed that engaging the partnerships between farmers and farmer-leaders, and household and community levels can be very helpful for the future management, operation, and maintenance of the NHLIP project. The main findings obtained from this study can also be very useful for irrigation water management practices in Bokeo Province and other areas in Lao PDR.

\section{Acknowledgements}

The authors would like to acknowledge the assistance and support of the Water User Group (WUG) in Phaoudom District for their valuable insights and recommendations. The authors would also like to extend their thanks to the Southeast Asian Regional Center for Graduate Study and Research in Agriculture (SEARCA) for the financial support and administrative assistance.

\section{REFERENCES}

ADB 2015. Feasibility study for Nam Haad irrigation rehabilitation [online]. [Access 03.01.2017]. Available at: https://www.adb.org/sites/default/files/linked-documents/ 42203-02-lao-oth-01.pdf

Alan G.D. 2016. Radio stations in the Lao Democratic People's Republic [online]. [Access 01.02.2017]. Available at: http://www.asiawaves.net/lao-radio.htm

CePuder P., Nolz R. 2007. Irrigation management by means of soil moisture sensor technologies. Journal of Water and Land Development. No. 11 p. 79-90.

Dymerska A., GrabowsKa K., BanaszKiewicz B. 2012. Warunki pogodowe a plonowanie łubinu wąskolistnego (Lupinus angustifolius L.) w północnej Polsce [Weather conditions and the yielding of narrow-leaf lupine (Lupinus angustifolius L.) in northern Poland]. Woda-Środowisko-Obszary Wiejskie. T. 12. Z. 2 (38) p. 121-132.

GROENFELDT D., SUN P. 1997. The concept of participatory irrigation management. Medit. Vol. 8. No. 2 p. 45-48.

LAM W.F. 1996. Institutional design of public agencies and coproduction: A study of irrigation associations in Taiwan. World Development. Vol. 24. Iss. 6 p. 1039-1054.

Ministry of Agriculture and Forestry 2013. Feasibility study on Nam Haad left bank irrigation subproject in Pha Oudom District of Bokeo Province. Lao PDR: Nippon Koei pp. 206.

MiodUSZEWSKI W. 2006. Management of water resources in rural areas: The Polish approach. Journal of Water and Land Development. No. 10 p. 3-14.

Mirdamadi S.M., NAJAFABADI M.O., ARABSEYfi M. 2016. Effective factors on Hashtgerd farmers' participation rate in water optimum utilization. Water Harvesting Research. Vol. 1. Iss. 1 p. 12-21.

Noreldin T., Ouda S., Amer A. 2016. Agro-climatic zoning in Egypt to improve irrigation water management. Journal of Water and Land Development. No. 31 p. 113-117. DOI 10.1515/jwld-2016-0041.

Phonemany S., Kuntiyawichai K. 2016. Participation level of water user in irrigated water management: A case study of Ban Vern Kham Pumping irrigation 
project, Xaithani district, Vientiane capital, Lao PDR. KKU Engineering Journal. Vol. 43. Iss. 4 p. 215-220.

Sivangpheng O., Kangrang A., Chaleeraktrakoon C. 2014. Appraisal of agricultural system in Lao PDR. Bulgarian Journal of Agricultural Science. Vol. 20 p. 973-979.
YERCAN M. 2003. Management turning-over and participatory management of irrigation schemes: A case study of the Gediz River Basin in Turkey. Agricultural Water Management. Vol. 62. Iss. 3 p. 205-214.

\section{Kittiwet KUNTIYAWICHAI, Quan V. DAU, Saengdavanh INTHAVONG}

\section{Zaangażowanie społeczności w zarządzanie nawodnieniami w Laotańskiej Republice Ludowo-Demokratycznej}

\section{STRESZCZENIE}

Dla bezpieczeństwa wodnego istotne są zrównoważone zarządzanie zasobami wody i zaangażowanie społeczeństwa. W badaniach prezentowanych w niniejszej pracy dokonano oceny zaangażowania społeczności w zarządzanie nawodnieniami w ramach projektu Nam Haad Left Irrigation Project (NHLIP). Szczegółowo rozważano praktyki na poziomie gospodarstwa domowego i społeczności lokalnej oraz poziom uczestnictwa rolników w zarządzaniu nawodnieniami. Wyniki uzyskane z odpowiedzi respondentów wskazują, że znaczący udział w gospodarowaniu wodą do nawodnień upraw ryżu w ramach projektu mają mąż i żona. Wyniki świadczą również, że większość respondentów uczestniczy z dużym zaangażowaniem w projekcie, czego dowodem jest wysoka punktacja $(3,80) \mathrm{w}$ pięciostopniowej skali Likerta. Do określenia istotności każdego rodzaju aktywności i udziału rolnika w zarządzanie nawodnieniami w ramach projektu NHLIP zastosowano krokową regresję wieloraka, a standaryzowane równanie regresji opisujące poziom całkowitego zaangażowania ma postać: $Y=0,538 x_{1}$ $+0,831 x_{8}+0,534 x_{14}+0,607 x_{18}+7,572$. Podsumowując, wyniki badań wskazują chęć udziału i współpracy w ulepszaniu i zarządzaniu projektem NHLIP.

Słowa kluczowe: grupa użytkowników wody, krokowa regresja wieloraka, Statystyczny Pakiet dla Nauk Społecznych, zaangażowanie społeczności, zarzqdzanie nawodnieniami 